\title{
Anode Products of a Direct Ethanol PEM Fuel Cell in a Circulating Fuel Operation Mode
}

\author{
Kento TANEDA, ${ }^{*}$ Tomoyasu TANIYAMA, and Yohtaro YAMAZAKI
}

\begin{abstract}
Department of Innovative and Engineered Materials, Interdisciplinary Graduate school of Science and Engineering, Tokyo Institute of Technology (4259, Nagatsuta-cho, Midori-ku, Yokohama, Kanagawa, 226-8502, Japan)
\end{abstract}

\section{Received April 30, 2004 ; Accepted July 3, 2004}

\begin{abstract}
The anode products of a direct type polymer electrolyte membrane fuel cell, which uses ethanol as a fuel, are investigated. The cell is operated by circulating the fuel for 7 hours and anode liquid and gas products in the fuel are analyzed by gas chromatography. The main products are acetaldehyde for the liquid phase and carbon dioxide for the gas phase, indicating $\mathrm{C}-\mathrm{C}$ bond of ethanol is decomposed by catalytic oxidation.
\end{abstract}

Key Words : Direct Fuel Cell, Ethanol, PEMFC, DMFC

\section{Introduction}

As is well known, a direct type polymer electrolyte membrane (PEM) fuel cell using liquid fuel, in particular aqueous solutions, has great advantage for compact power generating systems, since no bulky additive components such as a fuel reformer are required. In fact, direct methanol fuel cells (DMFC) are now one of the most intensively researched and developed fuel cells. For practical use of the fuel cells, however, methanol has several disadvantages, one of which is the fact that methanof is toxic for human beings. To circumvent this problem, some methods to isolate methanol from human beings should be developed if methanol is used as a fuel in a portable system. Ruthenium, which exists rarely than platinum on the earth, is also necessary for an anode secondary catalyst in this system.

Several studies of direct type fuel cells using other fuels such as ethanol have been reported in this regard. ${ }^{1,2)}$ Ethanol has the big advantage of being harmless to human beings, which is one of the most important factors for a portable power system. The industrial biosynthesis method of ethanol has also been established, suggesting that biomass can be widely used as a source of the fuel.

Watanabe et al. ${ }^{3)}$ studied the catalytic oxidation activity of rare metal alloys for ethanol in 1975 and demonstrated a catalytic oxidation of ethanol using PtRu alloy. Wang et al. ${ }^{4}$ ) reported a direct type PEM fuel cell using a PtRu anode catalyst with water-ethanol mole ratios ranging from $2: 1$ to $5: 1$, and concluded that the dominant anode product was acetaldehyde rather than carbon dioxide. On the other hand, Arico et al. showed that the anode product was predominantly carbon dioxide, neither acetaldehyde nor acetic acid, using a diluted ethanol

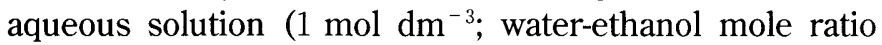
is 52:1) with a PtRu anode catalyst. They indicated the difference in the anode products might result in the difference in the ethanol concentration, however, the details are still in controversy.

The other species generated at the anode compartment should be investigated. For practical use, fuel must be circulated in the system and anode products will give an influence on the cell performance, however, no studies of anode products are reported. In this study, we carefully analyze the anode products in a circulating fuel system as a function of operating time. This is the first report of the analysis of anode products formed in a direct ethanol PEM fuel cell in a long time and circulating fuel operation.

\section{Experimental}

Membrane electrode assembles (MEAs) consisting of a PtRu anode catalyst (Pt loading: $2 \mathrm{mg} \mathrm{cm}^{-2}$, $\mathrm{Ru}$ loading: $1 \mathrm{mg} \mathrm{cm}^{-2}$ ), a Pt cathode catalyst (Pt loading: $2 \mathrm{mg}$ $\mathrm{cm}^{-2}$ ) and a Nafion $115^{\circledR}$ membrane as a polymer electrolyte were made by Electrochem Co. The cell holder, which holds the MEA, was also made by Electrochem Co. (FC05-01SP-REF). The cell was operated at $80^{\circ} \mathrm{C}$ at a constant cell voltage of $0.3 \mathrm{~V}$ or $0.05 \mathrm{~V}$ to investigate anode products. The concentration of an ethanol aqueous solution used for the operation was $0.5 \mathrm{~mol} \mathrm{dm}^{-3}(\mathrm{M})$, and the flow rate of the fuel was set at $5.0 \mathrm{ml} \mathrm{min}{ }^{-1}$ with no backpressure. As a cathode gas, humidified oxygen was supplied with a flow rate of $50 \mathrm{ml} \mathrm{min}^{-1}$ and no backpressure. As shown in Fig. 1, an ethanol solution with anode liquid products was circulated in the system. Anode gas was separated from the liquid-gas mixture and collected in an anode gas trap to analyze the gas products. The anode gas and liquid products were analyzed using a gas chromatograph (Shimadzu GC-8 AIT) 1 hour, 4 hours and 7 hours later from the beginning of each operation. The mole amount of gas was obtained from the volume and partial pressure of the gas under the assumption that temperature was $298 \mathrm{~K}$. The gas was treated as an ideal gas. 


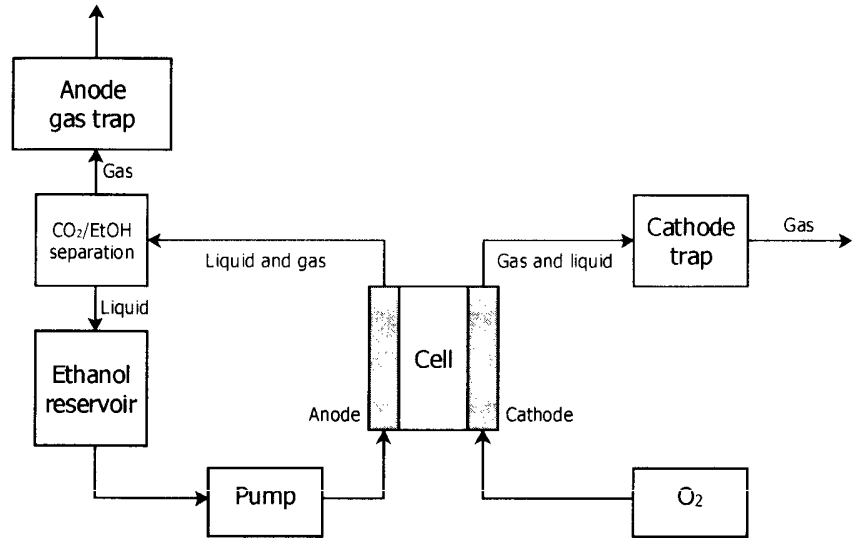

Fig. 1 Experimental set up for analyzing anode products in a direct ethanol fuel cell. Anode gas is separated from a liquidgas mixture and collected in a gas trap.
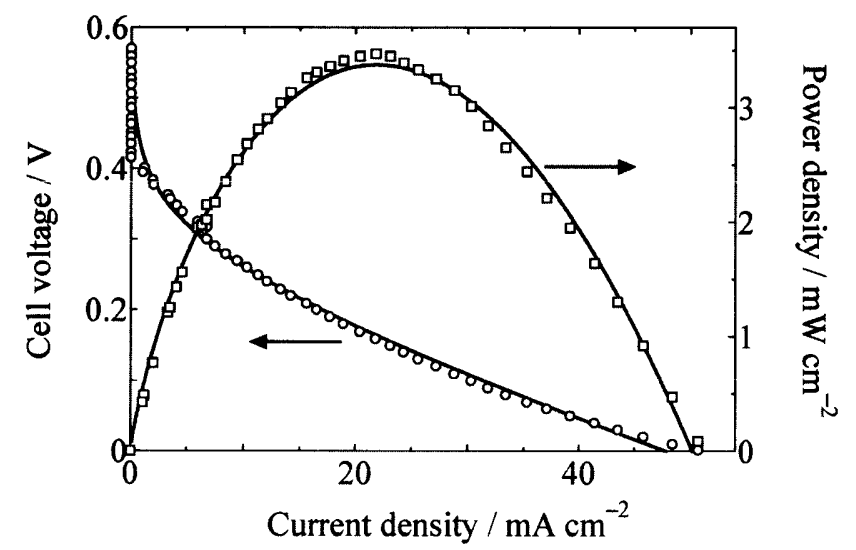

Fig. 2 I-V curve and power density curve. Ethanol concentration: $0.5 \mathrm{M}$, cell temperature: $80^{\circ} \mathrm{C}$, maximum power density: $3.5 \mathrm{~mW} \mathrm{~cm} \stackrel{2}{2}$.

\section{Results and Discussion}

As a preliminary experiment, an I-V curve and a power density curve were measured, as shown in Fig. 2. The observed limiting current density and maximum power density are $50 \mathrm{~mA} \mathrm{~cm} \mathrm{~cm}^{-2}$ and $3.5 \mathrm{~mW} \mathrm{~cm} \mathrm{~cm}^{-2}$, respectively, which are small compared to the results reported in Ref. 6 . The reason may be due to the difference between their experimental conditions and ours, e.g., the flow rate of cathode gas and backpressure, etc.

The time variation of the concentration of anode liquid products in a constant voltage operation is shown in Fig. 3. Acetaldehyde was the main product. Acetic acid was not detected. The concentration of acetaldehyde evidently increases as operating time elapses for both cell voltages of $0.3 \mathrm{~V}$ and $0.05 \mathrm{~V}$, indicating that ethanol is electro-catalytically oxidized into acetaldehyde by the $\mathrm{PtRu}$ anode catalyst. The concentration of ethanol is almost the same over the operating time examined. The logarithmic plots of concentration of acetaldehyde, on the other hand, increase monotonously with the operating time and the concentration of acetaldehyde at $0.05 \mathrm{~V}$ is much larger than that at $0.3 \mathrm{~V}$.

The time evolution of anode gas products is shown in Fig. 4. The main products are carbon dioxide and meth-

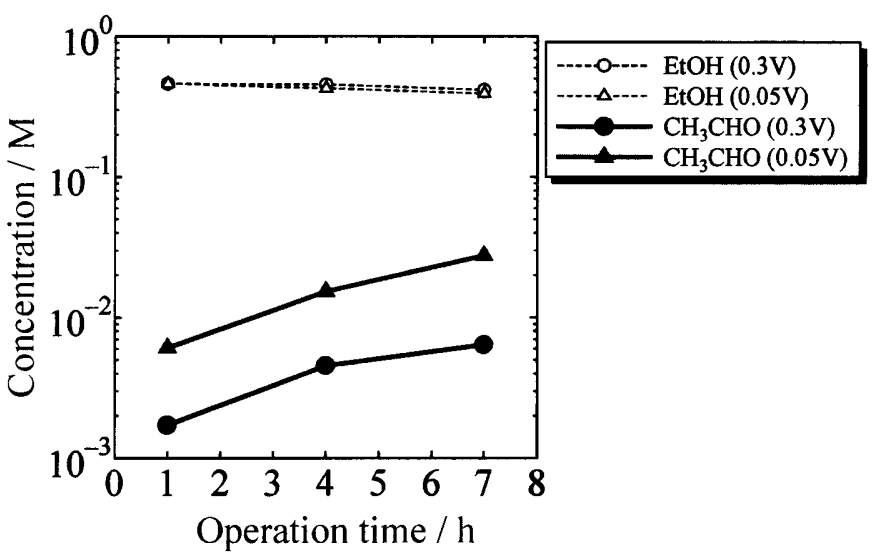

Fig. 3 Time dependence of the concentrations of anode liquid products. Fuel: $0.5 \mathrm{M}$ ethanol, cell temperature: $80^{\circ} \mathrm{C}$, fuel flow rate: $5.0 \mathrm{ml} \mathrm{min}{ }^{-1}$, cathode gas: $\mathrm{O}_{2}$ (humidified), $\mathrm{O}_{2}$ flow rate: $50 \mathrm{ml} \mathrm{min}^{-1}$, anode catalyst: $\mathrm{Pt} 2 \mathrm{mg} \mathrm{cm}^{-2}$, $\mathrm{Ru} 1 \mathrm{mg}$ $\mathrm{cm}^{-2}$, cathode catalyst: Pt $2 \mathrm{mg} \mathrm{cm}^{-2}$.

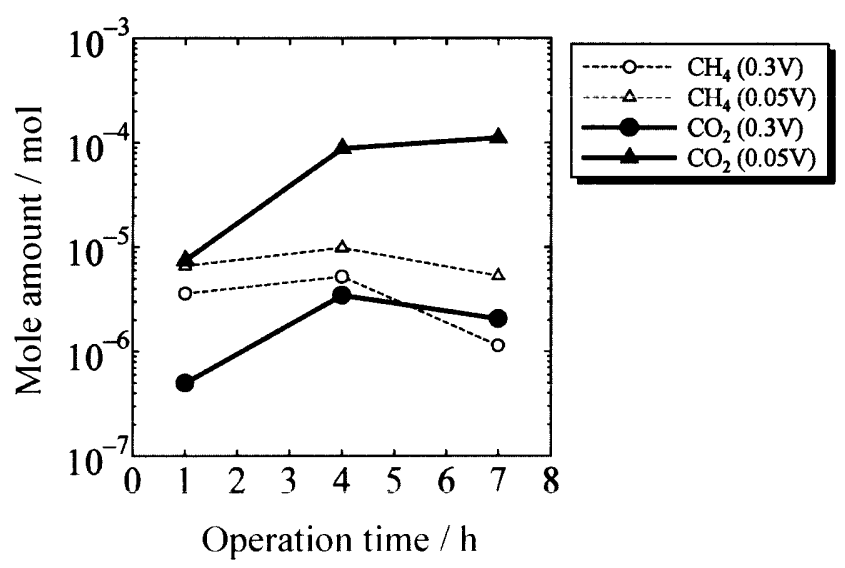

Fig. 4 Time dependence of the mole amounts of anode gas products. Fuel: $0.5 \mathrm{M}$ ethanol, cell temperature: $80^{\circ} \mathrm{C}$, fuel flow rate: $5.0 \mathrm{ml} \mathrm{min}{ }^{-1}$, cathode gas: $\mathrm{O}_{2}$ (humidified), $\mathrm{O}_{2}$ flow rate: $50 \mathrm{ml} \mathrm{min}^{-1}$, anode catalyst: $\mathrm{Pt} 2 \mathrm{mg} \mathrm{cm} \mathrm{cm}^{-2}, \mathrm{Ru} 1 \mathrm{mg}$ $\mathrm{cm}^{-2}$, cathode catalyst: Pt $2 \mathrm{mg} \mathrm{cm}^{-2}$.

ane. The mole amount of methane slightly decreases with the operating time for the cell voltages of $0.3 \mathrm{~V}$ and $0.05 \mathrm{~V}$. In contrast, the mole amount of carbon dioxide increases drastically with the operating time. In particular, at $0.05 \mathrm{~V}$, the mole amount at 7 hour is larger than that at 1 hour by a factor of 10 at $0.05 \mathrm{~V}$. It is clearly shown from Fig. 4 that much more carbon dioxide is generated at $0.05 \mathrm{~V}$ than that at $0.3 \mathrm{~V}$. From these results, we suggest that carbon dioxide and acetaldehyde are likely to be generated in catalytic reactions at the anode.

The mole ratios of products in liquid and gas phases obtained after 7 hours operation are shown in Table 1. The mole amounts of the liquid product are calculated from the concentrations of acetaldehyde and the volumes of the liquids, which are measured after the 7 hours operations. Acetaldehyde is the predominant product for the both voltages of $0.3 \mathrm{~V}$ and $0.05 \mathrm{~V}$. The mole ratio of carbon dioxide at $0.05 \mathrm{~V}$ is much larger than that at 0.3 $\mathrm{V}$ nearly by a factor of 6 . On the contrary, the ratio of 
Table 1 Mole ratios of products in liquid and gas phases after 7 hours operation.

\begin{tabular}{ccc}
\hline & \multicolumn{2}{c}{ Mole ratios } \\
\cline { 2 - 3 } Species & $0.3 \mathrm{~V}$ & $0.05 \mathrm{~V}$ \\
\hline $\mathrm{CH}_{3} \mathrm{CHO}$ & 0.88 & 0.72 \\
$\mathrm{CO}_{2}$ & 0.044 & 0.28 \\
$\mathrm{CH}_{4}$ & 0.073 & 0.0030 \\
\hline
\end{tabular}

methane at $0.05 \mathrm{~V}$ is smaller than that at $0.3 \mathrm{~V}$. These results show a reaction of ethanol forming carbon dioxide with PtRu anode catalyst.

Recently, Zhou et al ${ }^{6}{ }^{6}$ have reported that the performance of a direct type ethanol PEM fuel cell is enhanced when tin is used as an anode secondary catalyst instead of ruthenium. They reported an open circuit voltage of $0.811 \mathrm{~V}$ and a maximum power density of $52 \mathrm{~mW} \mathrm{~cm}$ using a PtSn alloy anode catalyst and a diluted ethanol solution at a moderate temperature $\left(90^{\circ} \mathrm{C}\right)$. Therefore, in view of cell performances, the use of PtSn might provide a greater performance than PtRu in the circulating fuel mode we have proposed. The effect of a different anode catalyst remains open for a future project.

\section{Conclusion}

By analyzing anode products in a circulating fuel operation with a constant cell voltage, we have shown that ethanol is oxidized into acetaldehyde and carbon dioxide using a PtRu anode catalyst. The appearance of carbon dioxide and methane indicates that the $\mathrm{C}-\mathrm{C}$ bond of ethanol is decomposed by catalytic oxidation. There are many studies to be explored on the effect of a different anode catalyst, concentration of a fuel, and cell operation temperatures.

\section{Acknowledgement}

The present work was financially supported by Grantin-Aid for Scientific Research on Priority Areas (B) of "New Technologies of DMFC" (No. 13134101) from MEXT.

\section{References}

1) Y. Yamazaki and K. Taneda, 71st Annual Meeting of the Electrochemical Society of Japan, Abstr., p.332 (2004) (in Japanese).

2) C. Lamy, A. Lima, V. LeRhun, F. Delime, C. Coutanceau, and J-M. Leger, J. Power Sources, 105, 283(2002).

3) M. Watanabe and T. Motoo, Denki Kagaku (presently Electrochemistry), 43, 153 (1975) (in Japanese).

4) J. Wang, S. Wasmus, and R. F. Savinell, J. Electrochem. Soc., 142, 4218 (1995).

5) A. S. Arico, P. Creti, P. L. Antonucci, and V. Antonucci, Electrochem. and Solid-State Lett., 1, 66 (1998).

6) W. Zhou, Z. Zhou, S. Song, W. Li, G. Sun, P. Tsiakaras, and Q. Xin, Applied Catalysis B: Environmental, 46, 273 (2003). 